Jurnal Kependudukan Indonesia | Edisi Khusus Demografi dan COVID-19, Juli 2020 | 109-114

JURNAL KEPENDUDUKAN INDONESIA

p-ISSN : 1907-2902 (Print)

e-ISSN : 2502-8537 (Online)

\title{
TEKNOLOGI KECERDASAN BUATAN, BIG DATA ANALYSIS, DAN INTERNET OF THINGS: POTENSI DAN PERANNYA DALAM PENANGANAN COVID-19 DI INDONESIA
}

\section{(ARTIFICIAL INTELLIGENCE TECHNOLOGY, BIG DATA ANALYSIS, AND INTERNET OF THINGS: THE POTENTIAL AND THE ROLE TO FIGHT COVID-19 IN INDONESIA)}

\author{
Syahrul Mubaroq ${ }^{1}$, Inas Mufidatul Insyiroh ${ }^{2 *}$ \\ ${ }^{1}$ Fakultas Matematika dan Ilmu Pengetahuan Alam, Universitas Gadjah Mada \\ ${ }^{2}$ Fakultas Ilmu Sosial dan Ilmu Politik, Universitas Gadjah Mada \\ *Korespondensi penulis: inas.mufidatul@gmail.com
}

\begin{abstract}
Coronavirus Disease 2019 (COVID-19) has spread throughout the world including Indonesia. The poor prevention and treatment of the initial phase results in a continuing increase in the number of positive cases and mortality caused by this virus. On the other hand, countries that have adopted policies that are fast and appropriate technology have been able to reduce the rate of additional cases and mortality rates. In this paper the authors conduct an analytical study of the application of technologies such as artificial intelligence, big data, and the internet of things in accelerating the detection, prevention, response, and recovery of COVID-19 cases in several countries and their possibilities to be applied in Indonesia. The authors suggest the Indonesian government to apply appropriate policies and technologies to reduce the high growth of COVID-19 cases.
\end{abstract}

Keywords: artificial intelligence, big data, COVID-19, internet of things, technology

Respons pemerintah terhadap pandemi COVID-19 (Coronavirus Disease 2019) di Indonesia berjalan buruk. Penulis mendapati bahwa pemerintah terkesan bersikap menggampangkan ketika COVID-19 belum menyebar ke Indonesia. Koordinasi antarlembaga pun dinilai tak berjalan baik (Setyaningrum, 2020). Setelah virus ini masuk dan menyebar ke Indonesia, hingga 8 Juni kasus telah mencapai 32.033 pasien positif, dengan jumlah pasien sembuh sebanyak 10.498 orang dan pasien meninggal sebanyak 1.883 orang (Gugus
Tugas Percepatan Penanganan, 2020). Pemerintah pun masih bergerak lamban. Pemerintah terlihat masih meraba-raba mekanisme yang tepat untuk menangani pandemi ini.

Kekurangan pemerintah dalam menangani pandemi ini terlihat setidaknya dari dua hal: pencegahan dan penanganan. Dari segi pencegahan, ada beberapa hal yang telah penulis lihat sebagai kekurangan. Pertama adalah kurang tanggapnya respons awal pasca pasien 
Jurnal Kependudukan Indonesia | Edisi Khusus Demografi dan COVID-19, Juli 2020 | 109-114

positif pertama terkonfirmasi, seperti lambatnya penetapan kebijakan terkait pembatasan aktivitas maupun pembatasan mobilitas orang. Poin kedua yakni kurang masifnya sosialisasi atau kampanye kepada masyarakat tentang bagaimana dan apa yang bisa mereka lakukan untuk melawan pandemi ini secara mandiri di awal-awal terjadinya. Akibatnya, masyarakat menjadi kurang waspada dan masih tetap beraktivitas di luar, meskipun telah dilarang melalui diberlakukannya kebijakan PSBB (Pembatasan Sosial Berskala Besar) di beberapa daerah (Firdausya, 2020).

Dari segi penanganan, kekurangan pemerintah terletak pada lambatnya penyediaan fasilitas kesehatan khusus untuk menangani kasus COVID-19, baik untuk pengujian maupun untuk perawatan. Untuk pengujian sendiri, baru tersedia 3 unit laboratorium ketika kasus positif pertama terkonfirmasi. Sedangkan untuk keperluan perawatan, seharusnya dibutuhkan perlengkapan dan ruang isolasi yang memadai bagi pasien positif. Namun ternyata hal tersebut belum mencukupi, antara lain terlihat dari ketersediaan alat pelindung diri (APD) bagi petugas medis saja yang masih kurang memadai (Bernie, 2020a). Hal ini berakibat pada adanya pasien COVID-19 yang ditelantarkan karena tidak mencukupinya kapasitas rumah sakit. Hal tersebut diperparah dengan lambatnya proses uji swab yang memakan waktu lebih dari 3 hari (Bernie, 2020b), dan berakibat pada terlambatnya penanganan sekaligus proses tracing orang-orang yang berinteraksi dengan pasien positif, pasien dalam pengawasan (PDP), dan orang dalam pemantauan (ODP).

Gambar 1. Tampilan grafik data penambahan kasus harian di Indonesia

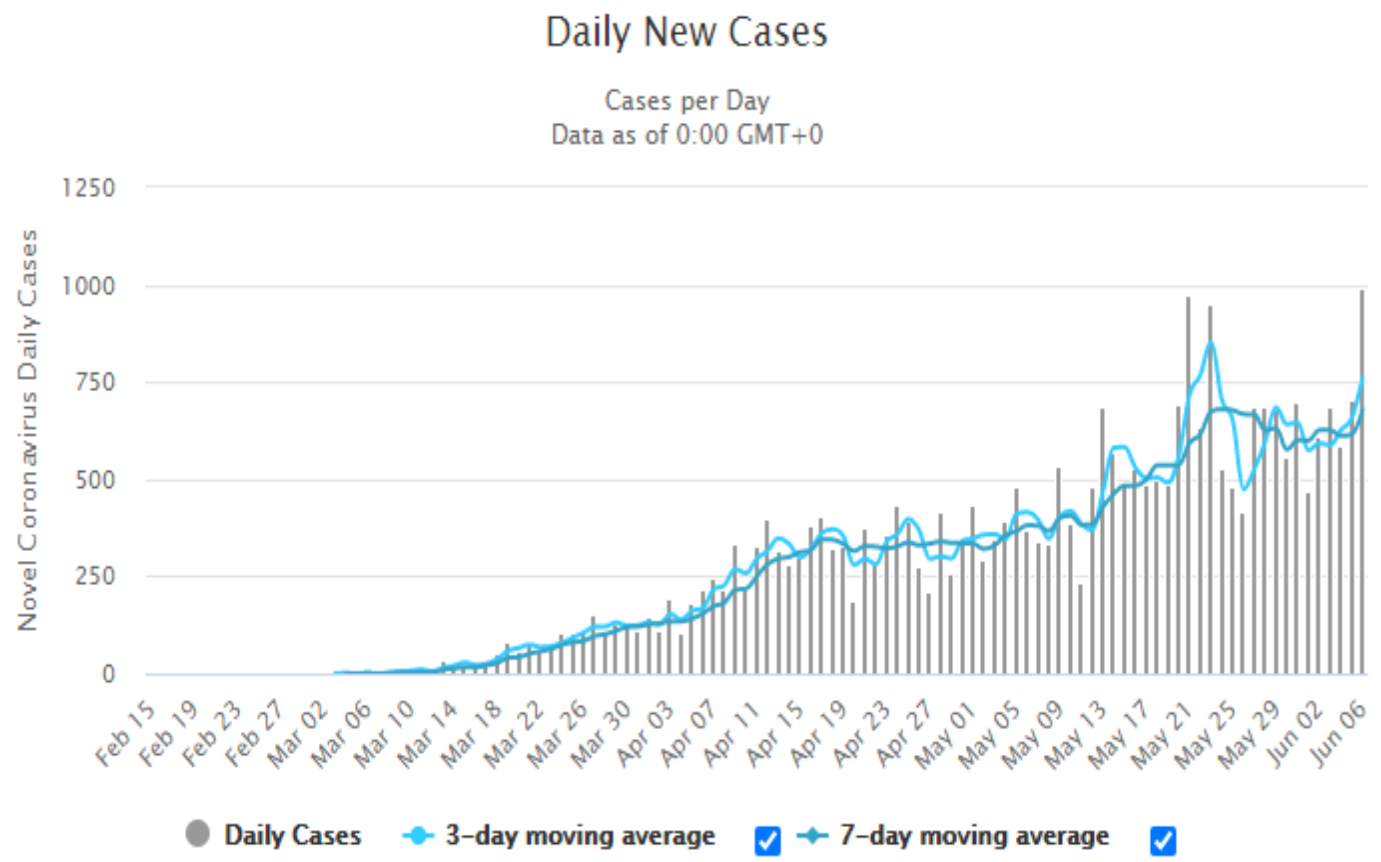

Sumber: Worldometers, 2020

Langkah-langkah yang telah dilakukan oleh pemerintah selama ini pun masih kurang efektif dalam menekan laju pertumbuhan jumlah kasus positif. Padahal, di sisi lain, data menunjukkan bahwa jumlah pasien positif terinfeksi COVID-19 di Indonesia masih terus meningkat hingga saat ini, seperti terlihat pada Gambar 1. Kondisi ini ditambah lagi dengan adanya fakta bahwa Indonesia masih belum memiliki kurva epidemi. Kurva epidemi memiliki peran penting sebagai penunjuk kronologi pandemi, dimulai dari perjalanan pandemi, dimulai dari kapan dan bersumber dari mana, kapan perkiraan puncak pandemi, dan kapan kira-kira pandemi berakhir. Selain itu, kurva ini juga berfungsi untuk menganalisis apakah langkah dan kebijakan yang dilakukan pemerintah telah tepat sasaran dan berjalan efektif atau tidak (Elyazar dkk., 2020). Ketiadaan kurva epidemi ini mengakibatkan tidak adanya indikator dan gambaran yang jelas 
tentang jumlah kasus. Hal ini kemudian berimbas pada sulitnya proses identifikasi kapan kira-kira kasus akan mulai mengalami penurunan angka dan kapan kasus berakhir.

Dari penjabaran tersebut, pemerintah memerlukan suatu tindakan yang lebih terukur, efektif, serta relevan dibandingkan dengan tindakan yang sekarang telah diambil, setidaknya hingga Indonesia memiliki kurva epidemik yang sesuai dengan standar keilmuan. Tindakan ini bisa dimulai dengan cara memberikan indikator keberhasilan yang jelas atas kebijakan PSBB yang telah diterapkan di beberapa daerah. Indikator keberhasilan ini diperlukan agar masyarakat tidak bingung apakah kebijakan PSBB tersebut efektif atau tidak dalam menekan laju pertumbuhan kasus positif terinfeksi COVID-19.

Gambar 2. Gambar perbandingan penambahan jumlah kasus terkonfirmasi COVID-19 di beberapa negara dengan Indonesia

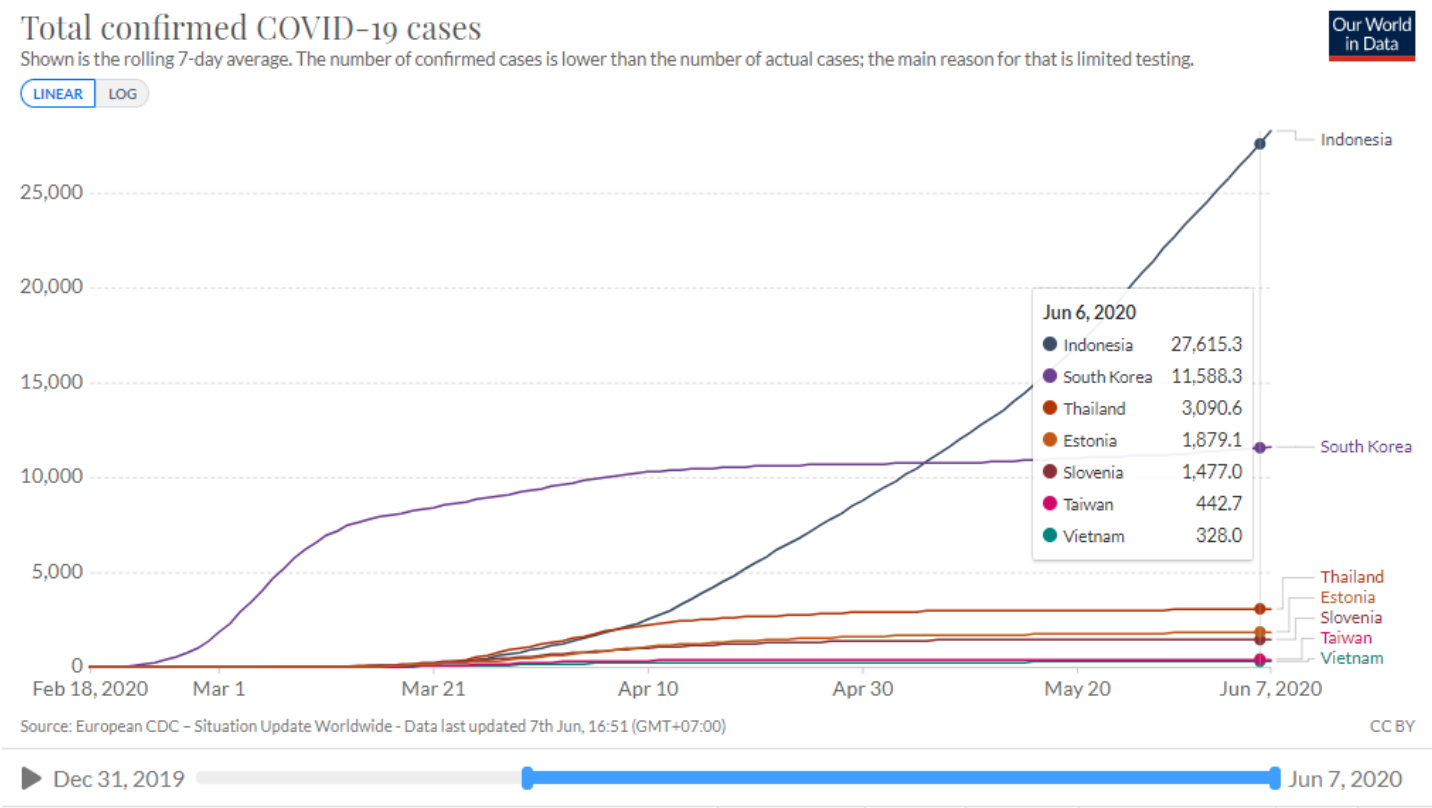

Sumber: Roser dkk., 2020

Seperti terlihat pada Gambar 2, jika dibandingkan dengan negara seperti Korea Selatan, Thailand, Estonia, Slovenia, Taiwan, dan Vietnam, Indonesia masih mengalami kenaikan jumlah kasus yang signifikan. Hal ini disebabkan karena mekanisme penanganan COVID-19 di Indonesia terbilang masih belum efektif dalam menekan laju pertumbuhan pasien positif. Hingga saat ini, telah ada beberapa negara yang berhasil menangani COVID-19, di mana mekanisme penanganan pandemi yang mereka lakukan bisa diadopsi oleh Indonesia. Dilansir dari Vox.com, beberapa negara yang berhasil tersebut di antaranya adalah Vietnam, Taiwan, Korea Selatan, Slovenia, Yordania, Islandia, Tiongkok, dan beberapa negara lain. Masing-masing negara tersebut memiliki cara yang berbeda dalam menangani, menanggulangi, dan mencegah penyebaran COVID-19, namun mekanisme yang mereka lakukan memiliki beberapa kesamaan, yakni menerapkan pembatasan sosial dengan ketat, melakukan tes dan tracing secara masif kepada penduduk, mengisolasi pasien yang terindikasi positif, memanfaatkan teknologi dalam penanganan COVID19, melakukan tindakan-tindakan preventif seperti himbauan untuk mengenakan masker kepada para penduduk, bersifat terbuka kepada masyarakat mengenai info-info terkait perkembangan COVID-19, dan tak sedikit juga negara yang menerapkan lockdown (Ward, 2020).

\section{Pemanfaatan Teknologi Untuk Mengatasi Pandemi}

Selain menerapkan kebijakan-kebijakan manual di atas, perang melawan pandemi COVID-19 juga dapat dilakukan dengan memanfaatkan kemajuan teknologi. Tercatat ada beberapa teknologi yang muncul di era revolusi industri 4.0 yang berguna bagi penanganan COVID-19, yakni artificial intelligence (AI), big data, internet of things (IoT), virtual reality (VR), holography, cloud computing, autonomous robot, $3 D$ 
scanning, 3D printing, dan biosensor (Javaid dkk., 2020). Dari banyaknya teknologi tersebut, yang sering kali muncul ke permukaan dan menjadi perbincangan adalah AI, big data, dan IoT. Hal ini karena penggunaan tiga teknologi tersebut memiliki cakupan yang luas, baik dari segi fungsi maupun penggunanya. AI digunakan untuk banyak tujuan, di antaranya deteksi dini dan memprediksi wabah, pembuatan robot, memproduksi $C T$ scan yang berguna untuk mendeteksi pneumonia dalam diri seseorang, dan berbagai kegunaan lainnya untuk mendukung sistem jaminan kesehatan. Big data digunakan dalam hal melakukan tracking dengan data yang bersifat real time, serta menganalisis dan memprediksi sejauh mana COVID-19 dapat menginfeksi masyarakat serta apa saja dampaknya. Sedangkan IoT yang terintegrasi dengan big data dapat menjadi sumber data tracing dan tracking. IoT juga berguna untuk mendukung sistem pengawasan warga selama menjalani karantina ataupun pasien saat berada di rumah sakit, serta dapat menjadi sistem pengawasan pembatasan sosial dengan menggunakan drone ataupun Closed Circuit Television (CCTV) (Javaid dkk., 2020).

Dalam menangani pandemi ini, pemerintah dapat mengimplementasikan kebijakan yang bersifat manual seperti pembatasan sosial dengan ketat, dikombinasikan dengan pengimplementasian teknologi-teknologi di atas. Menurut berbagai sumber, telah ada beberapa mekanisme penanganan atau pencegahan yang memanfaatkan teknologi dalam menghadapi pandemi ini, yakni location tracking yang melacak keberadaan dan riwayat perjalanan seseorang melalui data lokasi ponselnya. Cara ini telah dilakukan oleh Korea Selatan, Tiongkok, Taiwan, Jerman, dan Italia. Selain itu, big data analysis yang terintegrasi dengan smart CCTV, media sosial, dan data lainnya yang relevan juga digunakan oleh Tiongkok untuk melakukan pengawasan terhadap masyarakatnya pada saat lockdown di beberapa wilayahnya (Huang dkk., 2020).

Selain Tiongkok, Korea Selatan pun menerapkan teknologi IoT, big data analysis, dan AI dalam upaya mengurangi jumlah persebaran virus COVID-19 di masyarakat. Hal ini terbukti efektif, khususnya karena penerapannya dilakukan untuk mengawasi pergerakan masyarakat guna mengetahui daerah mana saja yang dikunjungi oleh warga. Apabila seseorang dinyatakan positif COVID-19, maka daerah-daerah yang telah dikunjunginya akan diumumkan oleh otoritas terkait melalui laman coronamap.live. Masyarakat yang dalam waktu bersamaan ada di tempat tersebut akan diberi tahu untuk melakukan tes COVID-19 secara mandiri di tempat tes yang telah ditentukan, sehingga laju penyebaraan bisa ditekan dan kebijakan lockdown tidak perlu dilakukan oleh pemerintah Korea Selatan (Park dkk., 2020).

Mekanisme penanganan Covid-19 selanjutnya yang memanfaatkan teknologi dan big data adalah aplikasi ponsel yang bisa diunduh dan diakses secara luas oleh masyarakat. Pemanfaatan teknologi berbasis aplikasi ponsel ini telah dilakukan oleh beberapa negara seperti Korea Selatan, Inggris, dan India. Meskipun teknologi aplikasi yang mereka kembangkan berbeda, namun fungsinya hampir serupa, yakni menginformasikan kepada pengguna apabila mereka ada di dekat orang atau berada di lokasi yang terinfeksi COVID-19.

Selain itu, teknologi AI juga dimanfaatkan dalam menangani pandemi ini. Tiongkok, khususnya rumah sakit Beijing, menggunakan AI untuk mengidentifikasi foto rontgen paru-paru yang terkena COVID-19 (Ting dkk., 2020). Negara ini juga menerapkan sistem pengenalan wajah bagi penduduk yang tidak mengenakan masker. Lebih jauh lagi, Tiongkok juga membuat robot dan drone khusus untuk dapat mengendalikan angka infeksi positif COVID-19 ini. Robot digunakan untuk membantu tenaga medis dalam merawat dan mengawasi pasien agar risiko tenaga medis tertular COVID-19 bisa ditekan serendah mungkin. Selain Tiongkok, Singapura juga mengadopsi teknologi ini. Sedangkan drone digunakan untuk menertibkan kerumunan dan menyuruh mereka untuk segera kembali ke rumah masing-masing (Seetharaman, 2020).

Teknologi yang diterapkan di beberapa negara tersebut, khususnya Korea Selatan, seharusnya bisa digunakan di Indonesia, mengingat pemerintah Indonesia tidak melakukan lockdown, tetapi memilih menerapkan PSBB di beberapa daerah. Dilihat dari kebutuhannya, pada tahap seperti sekarang ini, pemerintah dapat menerapkan big data analysis dengan mengintegrasikan data tracing pasien positif COVID-19, data kependudukan, data dari aplikasi PeduliLindungi, data dari CCTV, dan beberapa data yang relevan untuk dapat ditampilkan dalam peta 
lokasi yang sebelumnya pernah dikunjungi pasien positif, lalu memberikan peringatan kepada orangorang yang sedang berada di daerah tersebut, atau yang secara bersamaan sedang berada di daerah tersebut, sehingga mempermudah tracing klaster kasus positif COVID-19 dan mengurangi risiko penularan lanjutan. Selain itu, teknologi AI dapat digunakan untuk proses deteksi dini COVID-19 dengan akurasi di atas $70 \%$. Cara ini telah dilakukan pengujiannya di China dengan menganalisis foto rontgen paru-paru (Mei dkk., 2020). Teknologi ini dapat pula dikembangkan di Indonesia mengingat sudah banyak peneliti maupun perusahaan teknologi di Indonesia yang mengembangkan teknologi AI.

Penggunaan teknologi seperti AI, IoT, dan pemanfaatan big data analysis, utamanya yang berhubungan dengan data kependudukan, penting untuk dilakukan sebagai salah satu langkah dalam memerangi pandemi COVID-19 ini. Pengaplikasian teknologi-teknologi di atas penting karena berfungsi sebagai pendukung bagi kebijakan-kebijakan serta langkah yang telah dilakukan oleh pemerintah untuk memerangi wabah ini. Hal ini telah dibuktikan oleh negara-negara yang berhasil menangani wabah dengan memberlakukan protokol kesehatan yang ketat sekaligus didukung dengan pemanfaatan teknologi yang telah kami sebutkan di atas. Menurut Organisation for Economic Co-operation and Development (OECD), peran teknologi seperti AI ini bahkan bisa menjangkau cakupan yang luas dalam masyarakat. AI bisa membantu kinerja pemerintah, petugas medis, serta masyarakat umum untuk bisa bersama-sama memerangi pandemi. Penggunaan teknologi seperti AI pun dapat dilakukan mulai dari tahap deteksi (detection), pencegahan (prevention), penanganan (response), dan pemulihan (recovery) (OECD, 2020).

\section{KESIMPULAN}

Pandemi COVID-19 di Indonesia telah menyebar dengan cepat di berbagai daerah dan telah memakan banyak korban jiwa. Beberapa kebijakan telah diimplementasikan, seperti misalnya pembentukan
Gugus Tugas COVID-19, penerapan PSBB, tes swab, rapid test, dan beberapa kebijakan lainnya, namun peningkatan jumlah pasien positif masih terjadi. Jika menilik dari bagaimana negara lain berhasil menangani wabah ini, mereka bukan hanya mengimplementasikan kebijakan-kebijakan yang sifatnya manual seperti di atas, melainkan didukung pula dengan penerapan teknologi. Beberapa teknologi yang dipakai adalah AI, IoT, dan big data. Pemanfaatan teknologi-teknologi tersebut terbukti efektif untuk membantu mengendalikan COVID-19. Penulis berargumen bahwa pemerintah Indonesia pun perlu menerapkan teknologi-teknologi yang relevan dengan apa yang Indonesia butuhkan, seperti mengintegrasikan aplikasi-aplikasi yang telah dibuat oleh pemerintah, baik di tingkat pusat maupun daerah; mengembangkan IoT dalam sistem tracing, tracking, dan pengawasan pasien positif, ODP, dan PDP; serta mengintegrasikan data kependudukan dan data-data terkait COVID-19 untuk kemudian dijadikan sistem big data, yang hasilnya dapat dianalisis untuk membuat kebijakan serta menjadi dasar informasi kepada masyarakat guna menekan laju pertumbuhan kasus COVID-19. Selain itu, mengembangkan dan menerapkan teknologi AI di bidang medis, khususnya diagnosis serta di bidang kesehatan masyarakat dapat mempermudah dan mengefisienkan penanganan COVID-19.

Pemanfaatan teknologi tersebut penting untuk dilakukan oleh pemerintah Indonesia karena mampu mendukung pengimplementasian kebijakan yang sifatnya manual seperti PSBB. Bahkan, pengimplementasian teknologi yang telah kami jelaskan tadi juga dapat mendukung langkah pemerintah dalam mengendalikan COVID-19 pada tahap deteksi, penanganan, pencegahan, dan pemulihan. Implementasi kebijakan pembatasan sosial yang ketat, disertai dengan pemanfaatan teknologi seperti AI, IoT, dan big data terbukti efektif dalam mengendalikan pandemi COVID-19 di negara lain. Jika Indonesia turut mengadopsi cara tersebut dengan langkah yang tepat, konsisten, dan disiplin, tidak menutup kemungkinan angka penularan atau kenaikan jumlah pasien positif dapat dikendalikan. 


\section{DAFTAR PUSTAKA}

Bernie, M. (2020a, Maret 24). APD Tak Merata, Tenaga Kesehatan di Daerah Jalani "Misi Bunuh Diri". Tirto.id. https://tirto.id/apd-takmerata-tenaga-kesehatan-di-daerah-jalanimisi-bunuh-diri-eG83

.(2020b, Mei 8). Di Balik Rumitnya Penentuan Skala Prioritas Tes Swab COVID19. tirto.id. https://tirto.id/di-balik-rumitnyapenentuan-skala-prioritas-tes-swab-covid-19fnjh

Elyazar, I., Lestari, K. D., Ekawati, L. L., \& Lina, R. N. (2020, Mei 8). Indonesia belum punya kurva epidemi COVID-19: Kita harus hatihati membaca klaim pemerintah kasus baru melambat. The Conversation. http://theconversation.com/indonesia-belumpunya-kurva-epidemi-covid-19-kita-harushati-hati-membaca-klaim-pemerintah-kasusbaru-melambat-137497

Firdausya, I. (2020, Maret 17). Mendikbud Sesalkan Masih Banyak Warga Beraktivitas di Luar Rumah. Media indonesia https://mediaindonesia.com/read/detail/297129 -mendikbud-sesalkan-masih-banyak-wargaberaktivitas-di-luar-rumah

Gugus Tugas Percepatan Penanganan. (2020). Peta Sebaran | Gugus Tugas Percepatan Penanganan COVID-19. Covid19.Go.Id. https://covid19.go.id/peta-sebaran

Huang, H., Peng, Z., Wu, H., \& Xie, Q. (2020). A big data analysis on the five dimensions of emergency management information in the early stage of COVID-19 in China. Journal of Chinese Governance, 5(2), 213-233. https://doi.org/10.1080/23812346.2020.17449 23

Javaid, M., Haleem, A., Vaishya, R., Bahl, S., Suman, R., \& Vaish, A. (2020). Industry 4.0 technologies and their applications in fighting COVID-19 pandemic. Diabetes \& Metabolic Syndrome. Clinical Research \& Reviews, 14(4), 419-422. https://doi.org/10.1016/j.dsx.2020.04.032

Mei, X., Lee, H.-C., Diao, K., Huang, M., Lin, B., Liu, C., Xie, Z., Ma, Y., Robson, P. M., Chung, M., Bernheim, A., Mani, V., Calcagno, C., Li, K., Li, S., Shan, H., Lv, J., Zhao, T., Xia, J., ... Yang, Y. (2020). Artificial intelligence- enabled rapid diagnosis of patients with COVID-19. Nature Medicine. https://doi.org/10.1038/s41591-020-0931-3

Organisation for Economic Co-operation and Development [OECD].(2020) Using artificial intelligence to help combat COVID-19. OECD Policy Responses to Coronavirus (COVID19).https://www.oecd.org/coronavirus/policyresponses/using-artificial-intelligence-to-helpcombat-covid-19-ae4c5c21/

Park, S., Choi, G. J., \& Ko, H. (2020). Information Technology-Based Tracing Strategy in Response to COVID-19 in South KoreaPrivacy Controversies. JAMA, 323(21), 2129. https://doi.org/10.1001/jama.2020.6602

Roser, M., Ritchie, H., Ortiz-Ospina, E., \& Hasell, J. (2020). Coronavirus Pandemic (COVID-19). Our World in Data. https://ourworldindata.org/coronavirus/country /indonesia

Seetharaman, G. (2020, March 29). Technology against coronavirus: How countries are using technology to fight coronavirus. The Economic Times. https://economictimes.indiatimes.com/tech/sof tware/how-countries-are-using-technology-tofight-coronavirus/articleshow/74867177.cms

Setyaningrum. (2020, April 29). Nilai Buruk Penanganan Corona di Indonesia, Pakar Beberkan Kekurangan Pemerintah. Warta Ekonomi.

https://www.wartaekonomi.co.id/read283332/ nilai-buruk-penanganan-corona-di-indonesiapakar-beberkan-kekurangan-pemerintah

Ting, D. S. W., Carin, L., Dzau, V., \& Wong, T. Y. (2020). Digital technology and COVID-19. Nature Medicine, 26(4), 459-461. https://doi.org/10.1038/s41591-020-0824-5

Ward, A. (2020, Mei 5). Vietnam, Slovenia, and 3 other overlooked coronavirus success stories. Vox.

https://www.vox.com/2020/5/5/21247837/cor onavirus-vietnam-slovenia-jordan-icelandgreece

Worldometers. (2020). Indonesia Coronavirus: 32,033 Cases and 1,883 Deaths. Worldometer. https://www.worldometers.info/coronavirus/co untry/indonesia/ 